\title{
Profil Pemahaman Nature of Models (NoM) Mata Pelajaran IPA Pada Siswa Kelas VIII SMP Negeri 3 Randudongkal Tahun Pelajaran 2019/2020
}

\author{
Cahyati Fitriyati, Joko Siswanto, Fenny Roshayanti
}

\section{(C) 2021 JEMS (Jurnal Edukasi Matematika dan Sains)}

This is an open access article under the CC-BY-SA license

(https://creativecommons.org/licenses/by-sa/4.0/) ISSN 2337-9049 (print), ISSN 2502-4671 (online)

\begin{abstract}
Abstrak:
Penelitian ini bertujuan untuk mendeskripsikan profil pemahaman Nature of Models (NoM) mata pelajaran IPA pada siswa kelas VIII SMP Negeri 3 Randudongkal Tahun Pelajaran 2019/2020. Subjek penelitian adalah siswa kelas VIII SMP Negeri 3 Randudongkal. Data dikumpulkan melalui metode tes yang dijabarkan berdasarkan indikator pemahaman Nature of Models (NoM). Berdasarkan hasil penelitian, al diperoleh rerata sebesar 56 , dengan rincian $23 \%$ siswa dengan kategori "bai" $k$, 54\% siswa dengan kategori "cukup",), dan 23 \% siswa dengan kategori "kurang".
\end{abstract}

Kata Kunci: pemahaman Nature of Models, IPA

\begin{abstract}
:
This study aims to describe the understanding profile of Nature of Models (NoM) in science subjects in class VIII students of SMP Negeri 3 Randudongkal for the 2019/2020 academic year. The research subjects were students of class VIII SMP Negeri 3 Randudongkal. Data was collected through a test method which was described based on the indicators of understanding Nature of Models (NoM). Based on the results of the study, al obtained an average of 56 , with details of $23 \%$ students in the "good" category, $54 \%$ students in the "enough" category, and $23 \%$ students in the "less" category.
\end{abstract}

Keywords: understanding of Nature of Models (NoM), IPA

\section{Pendahuluan}

Keadaan siswa dan tantangan yang dihadapi menjadi gambaran perlunya pemahaman stimulus yang baik pada siswa. Hasil penelitian pembelajaran yang menekankan pada pemahaman stimulus menunjukkan hasil yang optimal. Hasil penelitian Sujarwa dan Hidayati (2014) menunjukkan bahwa pada kegiatan modeling instruction seperti saat siswa diminta untuk memberi penjelasan konseptual atas pendapat dan jawaban baik secara lisan maupun tertulis serta pemberian masalah berdasarkan konsep dapatdijadikan sebagai alternatif lain dalam penilaian bukan hanya sebatas pada paper and pencil test saja. Sementara menurut Bamberger dan Davis (1993) sebagaimana dikutip Nurkholis (2019) Penelitian di USA melaporkan enam puluh lima siswa kelas enam dari satu guru sains di sekolah umum perkotaan di Midwestern USA siswa meningkat secara signifikan dalam beberapa pemodelan. Peningkatan ini berfungsi sebagai bukti bahwa instruksi berbasis model dapat membantu siswa memperoleh praktik pemodelan yang dapat mereka terapkan di area konten yang baru, dalam praktik pemodelan terdapat unsur yang digunakan dalam pemecahan masalah yaitu berfikir kreatif (Bamberger \& Davis, 2013). 
Istilah "model" sering digunakan untuk menggambarkan (antara lain) replika fisik benda atau sistem. Model molekul yang mengisi ruang angkasa terbuat dari plastik serta bola-bola materi dan bola lampu yang membentuk "model" tata surya adalah contoh dari model fisik. Sistem representasi, seperti peta atau diagram, dan algoritma atau rumus matematika juga disebut sebagai model. (Cartier, et al., 2001 dalam Nurkholis,2019)

Pengetahuan tentang model dan pengetahuan model yang dikombinasikan dan pengetahuan meta-pemodelan, dilengkapi dengan kemauan dan motivasi untuk menerapkan kemampuan yang terkait dengan model dalam situasi bermasalah akan membentuk kompetensi model. Adapun kerangka teori model dapat diuraikan sebagaimana tabel 1 berikut.

Tabel 1. Kerangka Teori Kompetensi Model

\begin{tabular}{|c|c|c|c|}
\hline Aspek & Level I & Level II & Level III \\
\hline Hakikat model & $\begin{array}{l}\text { Model adalah replikasi } \\
\text { yang asli }\end{array}$ & $\begin{array}{l}\text { Model adalah representasi } \\
\text { yang ideal dari aslinya }\end{array}$ & $\begin{array}{l}\text { Model adalah rekonstruksi } \\
\text { teoretis asli }\end{array}$ \\
\hline $\begin{array}{l}\text { Multiple } \\
\text { model }\end{array}$ & Objek model berbeda & $\begin{array}{l}\text { Original memungkinkan } \\
\text { pembuatan model yang } \\
\text { berbeda }\end{array}$ & $\begin{array}{l}\text { Hipotesis tentang aslinya } \\
\text { berbeda }\end{array}$ \\
\hline Tujuan model & $\begin{array}{l}\text { Menggunakan model } \\
\text { untukmenggambarkan } \\
\text { yang asli }\end{array}$ & $\begin{array}{l}\text { Menggunakan model } \\
\text { untuk menjelaskan sesuatu } \\
\text { tentang aslinya }\end{array}$ & $\begin{array}{l}\text { Menggunakan model } \\
\text { untuk memprediksi } \\
\text { sesuatu tentang aslinya }\end{array}$ \\
\hline Testing model & $\begin{array}{l}\text { Mengontrol/ } \\
\text { menggunakan objek } \\
\text { model }\end{array}$ & $\begin{array}{l}\text { Menggunakan model } \\
\text { dengan objek aslinya }\end{array}$ & $\begin{array}{l}\text { Menguji ide hipotesis asli } \\
\text { dengan modelnya }\end{array}$ \\
\hline $\begin{array}{l}\text { Changing } \\
\text { model }\end{array}$ & $\begin{array}{l}\text { Memperbaiki kesalahan } \\
\text { dalam objek model }\end{array}$ & $\begin{array}{llr}\text { Merevisi } & \text { model } & \text { karena } \\
\text { temuan } & \text { baru } & \text { tentang } \\
\text { aslinya } & & \end{array}$ & $\begin{array}{l}\text { Merevisi model karena } \\
\text { pemalsuan hipotesis asli } \\
\text { dnegan modelnya }\end{array}$ \\
\hline
\end{tabular}

(Gogolin dan Kruger, 2018)

Penelitian yang dilakukan Nurkholis (2018) menunjukan bahwa pemahaman Nature of Models siswa peminatan MIPA di SMA Negeri se-Kabupaten Pemalang termasuk dalam kategori "Cukup". Frekuensi siswa yang memiliki pemahaman kategori "Sangat Baik" yaitu $0,25 \%$. Frekuensi siswa yang memiliki pemahaman kategori "Baik" yaitu 42,75\%. Frekuensi siswa yang memiliki pemahaman kategori "Cukup" yaitu 54,00\%. Frekuensi siswa yang memiliki pemahaman kategori "Kurang" yaitu 3,00\%. Hasil pemahaman pada masingmasing indikator Nature of Models yaitu indikator 3 dengan nilai rata-rata 73,2 dan indikator yang memperoleh nilai rata-rata terendah yaitu indikator 4 sebesar 46,8.

Penelitian ini menjelaskan tentang profil pemahaman NOM siswa kelas VIII SMP N 3 Rdd tahun pelajaran 2019/2020 materi sistem gerak pada manusia. Diharapkan dengan data ini, guru dapat menentukan langkah yang tepat dalam penelitian maupun pembelajaran ke depan. Informasi ini dapat digunakan sebagai bahan evaluasi pembelajaran bagi guru, kepala sekolah, dan pihak lain yang berkepentingan.

\section{Metode}

Subyek dalam penelitian ini adalah siswa kelas VIII D SMP N 3 Rdd dengan jumlah keseluruhan 31 siswa dengan rincian 14 siswa laki-laki dan 20 siswa perempuan. Dipilihnya kelas VIII D sebagai subyek penelitian karena memiliki keberagaman yang tinggi dibanding delapan kelas lainnya. di satuan SMP Negeri 3 Randudongkal. Penelitian dilaksanakan pada awal semester tahun pelajaran 2019/2020 pada minggu I bulan Januari 2020.

Variabel penelitian ini adalah pemahaman NOM melalui pengukuran tes tertulis berbentuk soal esai. Soal dikembangkan dari lima indikator Nature of Models. Setiap indikator diwakili satu soal, sehingga secara keseluruhan terdapat lima soal esai. Setiap soal dinilai 
dengan skor 0-4 dengan kriteria masing-masing. Adapun kisi-kisi test tertulis dapat dilihat pada tabel 2 berikut.

Tabel 2. Kisi-kisi tes tertulis

\begin{tabular}{|c|c|c|}
\hline No. & Indikator & Kisi-kisi \\
\hline 1. & $\begin{array}{l}\text { Angka geometrik, urutan angka, grafik, } \\
\text { diagram, sketsa, garis angka, peta, dan } \\
\text { deskripsi lisan dan tertulis dapat digunakan } \\
\text { untuk merepresentasikan objek, peristiwa, dan } \\
\text { proses di dunia nyata }\end{array}$ & $\begin{array}{l}\text { Disajikan gambar suatu model, siswa dapat } \\
\text { menjelaskan fungsi dari model tersebut. }\end{array}$ \\
\hline 2. & $\begin{array}{l}\text { Sesuatu mirip dengan model tetapi } \\
\text { tidak persis seperti yang dimodelkan. }\end{array}$ & $\begin{array}{l}\text { Disajikan dua buah gambar model yang } \\
\text { berbeda, siswa dapat menjelaskan perbedaan } \\
\text { dan persamaan model tersebut dengan } \\
\text { keadaan sebenarnya }\end{array}$ \\
\hline 3. & $\begin{array}{l}\text { Model berguna untuk memikirkan objek, } \\
\text { peristiwa, dan proses dunia nyata. }\end{array}$ & $\begin{array}{l}\text { Disajikan gambar suatu model, siswa dapat } \\
\text { menjelaskan peristiwa yang dijelaskan model }\end{array}$ \\
\hline 4. & $\begin{array}{l}\text { Kegunaan model dalam berpikir } \\
\text { tentang objek, peristiwa,dan proses tergantung } \\
\text { pada seberapa dekat perilakunya sesuai } \\
\text { dengan aspek-aspek kunci dari apa yang } \\
\text { dimodelkan. }\end{array}$ & $\begin{array}{l}\text { Disajikan dua gambar model yang berbeda, } \\
\text { siswa dapat menjelaskan kedekatan masing- } \\
\text { masing model dengan aspek-aspek kunci } \\
\text { permodelan. }\end{array}$ \\
\hline 5. & $\begin{array}{l}\text { Tidak ada jaminan bahwa ide yang semata- } \\
\text { mata didasarkan pada model adalah benar. }\end{array}$ & $\begin{array}{l}\text { Disajikan suatu pernyataan, siswa dapat } \\
\text { mendeskripsikan kebenaran suatu model }\end{array}$ \\
\hline
\end{tabular}

Setelah semua data terkumpul, langkah berikutnya adalah data hasil tes kemampuan berpikir kratif dianalisis secara deskriptig dengan menghitung rerata, skror maksimun, dan starndar deviasi. Pengelompokkan hasil tes menggunakan klasifikasi dengan kriteria sebagaimana tabel 3 berikut:

Tabel 3. Kualifikasi Kriteria Pemahaman Nature of Models

\begin{tabular}{cc}
\hline Interval nilai rata-rata benar (\%) & Kriteria Literasi Lingkungan \\
\hline $81-100$ & Baik Sekali \\
$61-80$ & Baik \\
$41-60$ & Cukup \\
$21-40$ & Kurang \\
$\leq 21$ & Kurang Sekali \\
\hline
\end{tabular}

(Arikunto \& Abdul Jabar, 2010)

Selanjutnya, dilakukan analisis data untuk mengetahui skor rerata setiap indikator. Analisis data berguna untuk mengetahui skor rerata tiap indikator kemampuan berpikir kreatif siswa sehingga dapat diketahui besarnya kontribusi tiap-tiap indikator.

\section{Hasil dan Pembahasan}

Berikut hasil analisis data penelitian:

Tabel 4. Deskripsi umum pemahaman Nature of Models

\begin{tabular}{cc}
\hline Rerata skor & $\mathbf{5 6}$ \\
\hline Standar Deviasi & 13.11 \\
Skor maksimal & 80 \\
Skor minimal & 30 \\
\hline
\end{tabular}


Tabel 5. Tingkat pemahaman Nature of Models

\begin{tabular}{ccc}
\hline Kategori & Jumlah & Persentase \\
\hline Baik Sekali & 0 & $0 \%$ \\
Baik & 7 & $23 \%$ \\
Cukup & 17 & $55 \%$ \\
Kurang & 7 & $23 \%$ \\
\hline Kurang Sekali & 0 & $0 \%$ \\
\hline
\end{tabular}

Berdasrkan hasil penelitian, diketahui tingkat pemahaman NOM siswa sebesar 56 atau masuk kategori cukup. Sebanyak 7 siswa (23\%) memiliki tingkat pemahaman NOM dengan kategori baik, 17 siswa (55\%) dengan tingkat pemahaman NOM cukup, dan 7 siswa (23\%) termasuk dalam kategori kurang dalam pemahaman NOM. Sementara itu siswa yang berpredikat sangat baik pada pemahamn NOM belum ada. Hasil ini selanjutnya ditinjau sesuai dengan tisp-tiap indikatornya.

Tabel 6. Ketercapaian setiap indikator pemahaman Nature of Models

\begin{tabular}{|c|c|c|c|}
\hline Nomor & Indikator & Persentase & Kategori \\
\hline 1 & $\begin{array}{l}\text { Angka geometrik, urutan angka, grafik, diagram, sketsa, garis } \\
\text { angka, peta, dan deskripsi lisan dan tertulis dapat digunakan } \\
\text { untuk merepresentasikan objek, peristiwa, dan proses di dunia } \\
\text { nyata }\end{array}$ & $80 \%$ & Baik \\
\hline 2 & $\begin{array}{l}\text { Sesuatu mirip dengan model tetapi } \\
\text { tidak persis seperti yang dimodelkan. }\end{array}$ & $45 \%$ & Cukup \\
\hline 3 & $\begin{array}{l}\text { Model berguna untuk memikirkan objek, peristiwa, dan proses } \\
\text { dunia nyata. }\end{array}$ & $40 \%$ & Kurang \\
\hline 4 & $\begin{array}{l}\text { Kegunaan model dalam berpikir tentang objek, } \\
\text { peristiwa,dan proses tergantung pada seberapa dekat perilakunya } \\
\text { sesuai dengan aspek-aspek kunci dari apa yang dimodelkan. }\end{array}$ & $27 \%$ & Kurang \\
\hline 5 & $\begin{array}{l}\text { Tidak ada jaminan bahwa ide yang semata-mata didasarkan pada } \\
\text { model adalah benar. }\end{array}$ & $12 \%$ & $\begin{array}{c}\text { Kurang } \\
\text { sekali }\end{array}$ \\
\hline
\end{tabular}

Mengacu pada analisis data, ditunjukkan bahwa pada indicator 1 pemahaman NOM memberikan kontribusi tertinggi sebesar $80 \%$. Hal ini sesuai dengan kisi-kisi soal bahwa siswa mampu menjelaskan fungsi dari suatu model.

Sementara itu pemahaman NOM terendah terdapat pada indicator 5 hanya mencapai 12\%. Berdasarkan kisi-kisi soal diketahui bahwa siswa belum mampu mendeskripsikan kebenaran suatu model. Pencapaian yang rendah pada indicator 5 ini perlu diteliti lebih lanjut baik dari segi strukrur soal maupun pada proses pembelajaran.

Pencapaian skor rerata pada indicator 2 sebesar 45\% dan masuk dalam kategori cukup. Pada indicator 2 siswa diminta untuk menjelaskan perbedaan dan persamaan model tersebut dengan model yang sebenarnya. Pencapain skor pada indicator 2 sebesar $45 \%$ dan masuk dalam kategori cukup. Namun demikian indicator ini perlu mendapat perhatian bagi siswa. Ke depanya perlu dikaji langkah-langkah yang tepat dalam upaya meningkatkan pemahaman siswa sesuai indicator 2.

Berlanjut pada indicator 3 tentang pemahaman siswa bahwa model berguna untuk memikirkan objek, peristiwa, dan proses dunia nyata. Pencapain skor rerata indicator 3 mencapai $40 \%$ dan masuk dalam kategori cukup. Umumnya siswa baru memahami bahwa model hanya dapat digunakan untuk merepresentasikan aspek fenomena yang sudah ada.

Pada indikator keempat, siswa diminta memahami bahwa tidak ada jaminan bahwa ide yang semata-mata didasarkan pada model adalah benar. Padaindikator ini rerata 
pemahaman siswa hanya berada pada nilai $27 \%$. Artinya, secara umum pemahaman siswa baru sampai pada semakin mirip model dengan bentuk fisik aslinya maka semakin baik.

Hal ini sesuai dengan penelitian Hamdani (2012) pada penelitian tentan pengaruh model pembelajaran reproduksi tumbugan menggunakan alat peraga terhadap pemahaman konsep siswa SMP N 7 Bengkulu memberi pengaruh sebesar 31,51\%. Setyarini (2012) berpendapat bahwa pemanfaatan alat peraga IPA mampu meningkatkan pemahaman fisika siswa pada konsep pengukuran di SMP N 1 Bulupesantren Kebumen TP 2012/20012. Dengan demikian penggunaan alat peraga IPA bisa dipakai sebagai media alternatif pembelajaran IPA guna meningkatkan pemahaman siswa terhadap konsep fisika.

\section{Simpulan}

Pemahaman Nature of Models siswa kelas VIII SMP N 3 Randudongkal diperoleh rerata sebesar 56, dengan rincian sebanyak 7 siswa(23\%) berada pada kategori baik, 17 siswa berada pada kategori cukup(54\%), dan 7 siswa berada pada kategori kurang(23\%). Untuk meningkatkan pemahaman Nature of Models, guru perlu membiasakan kegiatan pembelajaran menggunakan model.Simpulan dan saran harus dituliskan pada bagian yang terpisah, sebagai berikut.

\section{Daftar Rujukan}

Arikunto, Suharsimi \& Abdul Jabar, Cepi Safrudin. 2010. Evaluasi Program Pendidikan. Jakarta: Bumi Aksara.

Hamdani D, Eva Kurniati dan Indra Sakti, 2012. Pengaruh Model Pembelajaran Generatif Dengan Menggunakan Alat Peraga Terhadap Pemahaman Konsep Cahaya Kelas VIII Di SMP Negeri 7 Kota Bengkulu. Jurnal Exacta, 10(1), 79-88.

Nurkholis, Afnan. 2019. Profil Pemahaman Nature Of Models (NoM) Siswa Peminatan MIPA SMA Negeri Se-Kabupaten Pemalang. Skripsi. Semarang : Universitas PGRI Semarang.

Prasetyarini A, Siska Desy Fatmaryanti, R. Wakhid Akhdinirwanto. Pemanfaatan Alat Peraga Ipa Untuk Peningkatan Pemahaman Konsep Fisika Pada Siswa SMP Negeri I Buluspesantren Kebumen Tahun Pelajaran 2012/2013. Purworejo: Universitas Muhammadiyah Purworejo.

Sujarwanto, E., \& Hidayat, A. (2014). Kemampuan Pemecahan Masalah Fisika Pada Modeling Instruction Pada Siswa SMA Kelas XI. Jurnal Pendidikan IPA Indonesia, $3(1), 65-78$. 